\title{
A new steps on to education theory
}

\author{
Jorayeva Sahibjamol Norkobilovna ${ }^{1}$, Pardayeva Mavluda Chori Qizi ${ }^{2}$ \\ ${ }^{1}$ Associate Professor of Uzbek language pedagogy and psychology, candidate of psychological, \\ sciences, Tashkent State Agrarian University, Uzbekistan \\ ${ }^{2}$ University: Tashkent State University of Uzbek language and literature named after Alisher Navoi, \\ Uzbekistan
}

\author{
Email:pardayeva.mavluda@gmail.com
}

\begin{abstract}
Education is an indispensable breath for the modern world. Because learning lies under all evolution. Therefore, today's sy population of the world who are already have realized this crucial respect focusing on education. So, the new curriculums and new ways are created for improvingtuitionn by them. A lot of researchers had been researching some enigmatic features of education. As a result of, those attempts there have been seen plenty of books and different types of articles. However in, contrast with them in this article has another approach for obstacles that are standing in front of the development.

The article reveals with the relay on so many experiments that what factors are becoming keys to open all doors in the education. These factors are expressed solutions with a comparison of some historical information like knowledge of Adam, Khobil's attempts, about there, were compulsion systems in some Muslim madrasas of Turkistan.
\end{abstract}

Keywords: Learning, Uzbek madrasas, life skill, compulsion, encouragement, habit.

\section{MEANS OF LEARNING}

Learning is heritage us from Adam. "(Quran 2:31-32) So, his next-generation always has been kept on learning something.

Education consists of multiple parts of the chain. The researches have described the chain according to different educational components. Many types of research attention to the chain of education from outside. For example, Alta van der Merwe and Johannes Cronje define The Educational Value China aa anasmodeling tool in reengineering efforts, conformity with Mahsa Dorri, Mohammad H. Yarmohammadian, Mohammad Ali Ladies' theory, they explanation value chain in higher education. We aim to describe the chain of education, the manner depends on student's inside features and people's life skills. Furthermore, the article reveals why some educational curriculums encounter failure and what things cause for this and shows some ways as a solution for that failure. So, through these parts, people can catch different unusual information about education. According to the findings of this research, there are a layered variety of parts that they related firmly to each and they promote to improve tuition.

Most people think that education is a relationship between teacher and student. However, education's border is extremely huge and has a number of different kinds of links that we haven't discovered yet. Moreover, those views that above mentioned have already been accepted by the people

Learners will be only one but the teacher might be a lot. It will be people, it will be animal or any kind of. If we must prove this theory we can bring the most illustration. For instance, you slip consequence collide to stone during walking with carelessly. Therefore, you may be careful tabouret time for such a situation. The Stone teaches you to become prudent. Adam's son Qobil also learned to the funeral from the crow. So, stone and crow teach us something. Thus, they are called teachers. You can't live with few knowledge that educators have given it during your entire life. There are other things' proportions to take knowledge from them. Life says: "you should learn me and learn from me. Hence, when you are talking about education, "teacher and learner" are more suit for that process, don't the only educator who are people and learners.

A lot of things in life rise the manner of connection. For instance, you go to the doctor to pain your legs but the doctor analyses your brain and he writes a list of medicines which for training your brain. Why the doctor does it?

Originally, all people interested to know the reason for that attempt. In this case, your legs tendons associates with some brain's tendons. So many other things have a connection with each like tendons. Fragments which can build a structure of Education impact each. hat feature might be all everything like finance, wishes, character, learner, teacher, and others. 


\section{WISHES AND CHARACTERS ARE THE BASIC CRITERIA TO LEARN}

Accepting a degree of knowledge is depends on people's characters and wishes. If new information is taught to two people, in spite of they have the same level, there are might be different results. Because they have. In spite of the fact that the pupil studying different kinds of programs, they can't make similar results pupil's temperesults optimist another's will be pessimists. An optimist can catch, up immediately when it comes to him any information. Opposite them, pessimists can't do it. But, this doesn't mean slow learners don't know anything else. These types of pupils also know a lot of other things as on their wishes and interests. They have also other types of intelligence. Some contemporary theorists tend to view intelligence as a general system like Charles Spearman. He was entirely quantitative, and proposed intelligence to be a 'general ability'. In his book (1927) he suggested a general factor of ability and some specific abilities as well. The concept of a general ability can be traced back to Galton, to the year 1869 when his book was published. General Ability in Britain was widely accepted and became part of the definition of intelligence and IQ tests. Cyril Burt (1937) advanced this idea further and applied it to mental retardation, which was then called mental subnormality in Britain. According to this definition, individuals with a mental deficiency were lagging behind in an innate general cognitive ability; their deficiency was mainly due to heredity (innate), and they were deficient in all aspects of mental ability. Recent conceptualization of intelligence can find faults with each of the terms in Burt's definition. Firstly, it is not innate because it can be molded by social-cultural learning. Certainly, it is not fixed, as Anderson (1989) remarks, because it grows albeit with constraints. Second, it is not general, according to several new researchers who have evidence for multiple intelligences (Das, Kirby and Jarman 1979; Gardner, 1993; Sternberg, 1985a, 1985b).In this section, we look at two widely studied contemporary theories of intelligence. The systems theories of intelligence differ from each other. We have described, some of the major aspects of the other approaches. The general trend in psychology seems to be toward broader rather than narrower conceptions of intelligence, in recognition of the fact that children and adults can be intelligent in many different ways. Howard Gardner's theory reveals us about multiple intelligences. They consist of: linguistic intelligence, logical-mathematical intelligence. In reality, melancholy and phlegmatic people's action is slower than choleric and sanguine so sometimes people have wrong imagination about those types of people. If some chocolate is given 2 children who have different character bustling children don't attention chocolate's color or size, he just wants only to eat it. Another patient children at first glance to the appearance of chocolate then begin eating it. Character marks plenty of things in this life. So while teaching pupils educators should take into consideration their individual character's feature.

Wishes are a strong power to prosper. Some students would be skillful but they haven't any wishes or interest in doing something, another type of despite being incapable they are active and have a desire to doing something. Their wishes stimulate them to try to front. Sake of, they can achieve a lot of success. When you focus your thoughts on something you want, and you hold that focus, you are in that moment summoning what you want with the mightiest power in the Universe. In the same ways parents against their children's wishes, they try to mark children's destiny, make a decision instead of them. This occasion switch off children's initiative and wishes. In the end, their interests with respect to urcurcuriosityityiosity disappear dramatically.

\section{THE ROLE OF COMPULSION AND ENCOURAGEMENT IN TEACHING}

Which one is effective for education compulsion or encouragement?. In Turkistan, (for a long Uzbekistan included Turkistan) had a lot of Muslim madrasas for teaching children. The madrasas consist of sections so, pupils taught from worldly and religious knowledge there. The teacher used different good and bad methods for teaching pupils. They have a special curriculum and discipline. Subjects separate from each other according to the interests of pupils. This is the advantage side of Muslim madrasas. Though In the other ways teachers use punishment in order to require taking knowledge, these ways couldn't justify itself for educated. For instantce, Sadriddin Ayniy reveals in his story called " The old school "some unusual ways of teaching. " Teacher asks their alfa (explanation) who helps the teacher during teaching:

Let's tell me who begins clamor? When Xalfa shows guilty. students stopped reading to listening but the teacher doesn't let children for listening to him. Then he compels children to read via stick". (Sadriddin Any. 1955). This method used the old education system, but now it is disappearing at all.

Some parents and teacher prefer compulsion for playful or lazy children and they can chalk up some results outcome have an influence on children for studying. They would be happy from their attempt ion after see children's achievement. But they don't know this progress isn't continuous. Children might do something as a result under control but this press limitations ss's children's inner spirit and consciousness. This approach badly impacts on children's own thinking way. Because of this compulsory, they get used to pacing from other's footsteps in usual life. Children hesitate and terrify before doing something. Making mistake become a dangerous process for them. So that, they may search for pretexts cause (ways) "If I make a mistake my mam or dad hit me or I can't do it, I have not affordable for doing it”. The pressure disappears student's confidence. Differentiate 
with pressure, encouragement gives stimulate to children and opens the new aspiration for acquiring other knowledge.

Researchers distinguish between intrinsic and extrinsic motivation in their studies of what motivates students most effectively( Covington, 2000; \& Mueller, 2001 )Intrinsic motivation is the push students give themselves; extrinsic motivation is the push students get from pursuing external rewards or incentives (Pintrich\&Schunk, 1996) It is essential to remember that these two types of motivation are not mutually exclusive - they can occur simultaneously as well as individually ( Covington \& Mueller, 2001; Lepper, Corpus, \&Iyengar, 2005). It is possible, and even desirable, to encourage students to use both intrinsic and extrinsic motivators. One Uzbek teacher has experienced according to know the level of intrinsic and extrinsic motivation. She gives awards to some pupils when their curiosity low while her teaching. Then, those children have appeared to stimulate study again. But if the teacher stops giving awards, children's activity also gets slack within that time. Although, other some student continue active study counting with their intrinsic motivation.

The practice reveals that intrinsic motivation is the best factor for researchers. Cause, it is born people's own possibility and inner spirit. This activity gives you enjoyment fromyyourselfWhen students have desires and goals they can make an intrinsic motivation. For example, one child is appeared to want to become a pilot. His desire and goal that to become to want pilot bring him intrinsic motivation.

Extrinsic motivation also works particularly well for young students. It comes from outside quarters to people. To illustrate, employers give awards to their workers often from time to time. This is a trap. Workers encourage from those awards and they try to work once more. Giving to children any awards in order to inspire is the same as the worker's situation. If put on trap permanently as an award to the children's way. They will tent to pursue knowledge. (I think it is a kind of motivation)

Overall, those two fragments are compulsion and encouragement urging to doing something. But acknowledge that, there are two parts of the method. Encouragement seems to be more effective than the compulsion to teach children.

\section{HABIT}

The next part of the chain is a habit. People have to catch good habits for themselves. The manner helps to found ate beautiful life. People's curiosity takes shape different habits. Some habits come and others leave during people's life. Habits aren't constantly. Be prepared always, so that when the opportunity comes knocking, you can take its full advantage. And also when people come across wise people, they have to copy that people's some good habits. But none doesn't attend to this at that time. This is also another hand to learning. People have super adaptability. Old people's standard of living to prove it. They had suited to a variety of situations to reach today's condition of living. Their adaptability has turned into habits from time to time. If students alter reading books to algorithmic habits there isn't breaking among the education's chain. According to Palani (2012), reading habit is an essential and important aspect for creating a literate society in this world. It shapes the personality of individuals and it helps them to develop proper thinking methods and creates new ideas. However, the developments in the Mass Media had continued to influence interest in reading books, magazines, and journals, among others. Some students used to accept knowledge by reading others used to accepting by listening. Thus their good habits help to create a nice atmosphere to learn something. Einstein said: "Life is like riding a bicycle. To keep your balance, you must keep moving". People should trap of balance in each part of chains during learning.

Life skills. Life skills have become a significant part of the f attainments of educational programs( Mutluer, 2013). The content of educational programs should be organized in a way to improve children's life skills (Sharma, 2003; Cert, 2014; Roselyne, 2014). As stated above, since 2013, the science course at the third and in the fourth grades has involved life skills. In previous science teaching programs, there was no learning domain related to life skills. Related learning domains were added by the science program, which was revised and became effective in 2013. In parallel to this new learning domain, one of the goals of the science education program is for students to assume responsibility for daily problems and employ the life skills taught in science courses to solve students' problems(MONE, 2013a: 1). On the other hand, the units related to life skills covered in science courses are as follows: "Living beings and life", "Matter and Change", "Physical events" and "The World and the Universe" (MONE, 2013a)

\section{ATMOSPHERE}

Another crucial side is becoming a fresh atmosphere to enhance education. As well as people can live well in a nice environment, education also can improve when there is comfort atmosphere. It depends on the staff of people and the government's regulation. If the government gives to citizen more opportunity to tuition, learners learning become easier. To create other free atmosphere depends on financial freedom. In this period almost all things 
associated with finance. And education too. If you have wishes, skills, and others but haven't ample money to doing something, you forced to absolutely focus on other things like to earn money. Some old people say: "Unless we had not enough opportunity, we tried to read so that achieved goal". They did do something in the former period. Therefore, their philosophy doesn't true for the present time. Life is always changeable. Because people's intellectual capacity also change with going to time. The most powerful children encounter a mishap consequence of financial defect.

In conclusion, readers might notice simple solutions to tough problems of education during reading each feature's content in this article. There are plenty of factors that people can pick up from them to pursue education. For example, habit. Factually, most people used to doing something in daily life. The outcome, these habits turn into one stable part of people's life. According to the same situation, a habit wherein the process of education also should turn into an important part of life. Such factors that can hold up the duration of education balance will be important guidance for the future.

\section{ACKNOWLEDGMENT}

God gave Adam the ability to identify and designate names to everything; He taught him language, speech, and the ability to communicate. God imbued Adam with an insatiable need for and love of knowledge. After Adam had learned the names and uses for all things God said to the Angels...

"'Tell me the names of these if you are truthful.' They answered 'Glory be to You, we have no knowledge except what You have taught us. Verily it is You the All-Knower, the All-Wise."' (Quran 2:31-32)

The Quran Translated to English by Talal Itani Published by Clear Quran Copyright (C 2009-2012 Talal A. Itani

\section{REFERENCES}

1. Burt, C. (1937). The backward child. London: London University Press.

2. Covington M, \&Myuller K ( 2001 ). Intrinsic vs, extrinsic motivation: An approach/avoidance reformulation. Educational Psychology Review, 157-176.

3. Galton, F. (1869). Hereditary Genius: An inquiry into its laws and consequence. London: D. Appleton.

4. Das, J.P., Kirby, J.R.\& Jarman, R. (1979). Simultaneous and successive cognitive processes. New York, NY: Academic.

5. Lepper, M., Corpus, J., \&Iyengar, S (2005). Intrinsic and extrinsic motivational orientations in the classroom: Age differences and academic differences. Journal of Educational Psychology.

6. Mahwish Rabia, Naima Mubarak., Hira Tallat, Wajiha Nasir. (2017). International Journal of Asian Social Science, 891-892

7. Pintrich, P. (2000). An achievement goal theory perspective on issues in motivation terminology, theory, and research. Contemporary Educational Psychology, 92-104.

8. Palani, K.K., 2012. Promising reading habits and creating literate social. International Reference Research Journal, 3(2): 90. Viewat Google Scholar Spearman, C. (1927). Abilities of man. London: Macmillan.

9. Srivastava, A.K., Tripathi, A.M., \& Misra, G. (1995). Western and Indian perspectives on intelligence: Some reflections. Indian Educational Review, 30, 30-45.

10. Sadriddin A. (1955). Old school,12. Uzbekistan SSR national publishing house. Tashkent.

11. MONE (2013). Science Teaching Curriculum (3rd,4th,5th, 6th, 7th and 8th grade) Ankara.

12. Mutluer,C.(2013).Sosyalbilgilerprogramlarındayeralanbecerilerhakkındasosyalbilgiler öğretmengörüşleri (İzmir menemenörneği). [The views of social studies teachers about the skills contained in social studies (The example of Izmir menemen)] Turkish Studies, 8(7),355-362.

13. Sharma, S. (2003). Measuring life skills of adolescents in a secondary school of Kathmandu: An experience. KathmanduUniversityMedicalJournal, 1(3), 170-176. 